\title{
Amyloid a Protein Amyloidosis in a Patient with Plasma Cell Dyscrasia
}

\author{
Hiroki Ishikawa, Keisuke Nakata, Tomoyuki Aritomi, Kazuaki Ohkubo, Kiyoshi Migita, Keisuke Hamasaki, \\ Satoshi YamasaKi, Kazuhiko NAKAO*, Yuji Kato, Tomayoshi HaYASHI** and Katsumi Eguchi
}

\begin{abstract}
We report a 59-year-old man who was found to have plasma cell dyscrasia and amyloid A protein (AA) amyloidosis during the follow-up period of chronic inactive hepatitis C. Clinical manifestations such as swallowing disturbance, proteinuria and leg edema were associated with AA amyloid deposits in his tongue and kidneys. Although the relationship between these two diseases remains to be determined, the ability of peripheral blood mononuclear cells to degradate serum amyloid A protein was apparently reduced in this patient, compared with normal volunteers. This would, in part, account for the AA amyloid deposition in this patient.

(Internal Medicine 41: 386-391, 2002)
\end{abstract}

Key words: $\mathrm{PBMC}, \mathrm{HCV}$, serum AA

\section{Introduction}

Amyloidosis is included in the diverse group of diseases characterized by the extracellular deposition of insoluble protein fibrils in organs and tissues $(1,2)$. The systemic or the local deposition of amyloid protein leads to mild to severe dysfunction of the involved organs; the prognosis of patients with amyloidosis, which varies according to the basal disease, is generally poor (3).

Systemic amyloidosis is classified into three types, based on the precursor proteins that form the fibril deposits (4). Amyloid light-chain (AL) amyloidosis is often associated with plasma cell dyscrasia in which clonally expanded plasma cells produce amyloidogenic immunoglobulins (5). Familial amyloidosis, an autosomal dominant disease, is caused by the mutation of the transthretin gene (6-8); peripheral sensorimotor and autonomic neuropathy is a common feature. On the other hand, secondary amyloidosis, defined as amyloid A protein
(AA) amyloidosis, occurs exclusively in patients with certain malignancies, chronic inflammatory diseases, and chronic infections $(9,10)$ in which the levels of serum amyloid A (SAA) protein, a precursor of AA amyloid are significantly elevated in a large proportion of the patients. However, clinical observations have shown that AA amyloidosis sometimes occurs in the absence of severe inflammation (11). Thus, the high level of SAA protein alone is not sufficient for amyloid formation, but rather the impaired catabolism of SAA protein is likely to result in AA amyloid deposition. In fact, the experimental studies indicate that the disrupted function of mononuclear cells which physiologically degradate SAA protein, is relevant to AA amyloid deposition $(12,13)$.

Here, we describe a patient with AA amyloidosis and plasma cell dyscrasia which were found during the follow-up period of chronic inactive hepatitis $\mathrm{C}$. We also ascertained a delayed degradation of SAA protein by peripheral blood mononuclear cells (PBMC) from the patient, compared with normal volunteers.

\section{Case Report}

A 59-year-old Japanese man was found to have mild liver dysfunction caused by chronic hepatitis $\mathrm{C}$ virus infection without any symptoms in 1992. In 1993, he was admitted to our hospital and underwent liver biopsy. The histologic finding of the liver tissue showed mild mononuclear cell infiltration with fibrosis in the portal area (Fig. 1). He was treated with interferon- $\alpha$; a total dose of 480 million units was given, but the serum level of aminotransferase could not be normalized or HCV-RNA remained positive during and after the treatment. In 1997, he noticed the swelling of the submandibular soft tissue. The swelling increased during the follow-up period, and caused dysphagia, dysarthria and snoring in addition to leg edema. Because of these symptoms, he was readmitted to our hospital in February 1998.

A physical examination on admission revealed macroglossia, diffuse swelling of the submandibular soft tissue, cervical

\footnotetext{
From the First Department of Internal Medicine, Nagasaki University School of Medicine, Nagasaki, *Health Research Center, Nagasaki University, Nagasaki and **Department of Pathology, Nagasaki University Hospital, Nagasaki 




and inguinal lymphadenopathy, mild hepatomegaly and edema in both legs. Neurological findings were almost normal. Urinalysis (Table 1) showed proteinuria and microscopic hematuria. As monitored by 24-hour urine protein analysis, the daily amount of proteinuria ranged from $1.9 \mathrm{~g}$ to $2.4 \mathrm{~g}$. Laboratory findings revealed a slight elevation of the erythrocyte sedimentation rate, hypoproteinemia, hypoalbuminemia, upper normal limits of asparate aminotransferase and alanine aminotransferase, and a slight elevation of serum C-reactive protein (CRP) and SAA protein. The antibody to hepatitis $\mathrm{C}$ virus $(\mathrm{HCV})$ was

Figure 1. Microscopic findings of the liver tissue, showing mild mononuclear cell infiltration and fibrosis in the portal area (HE stain, $\times 200$ ).

Table 1. Laboratory Data on Admission

\begin{tabular}{|c|c|c|c|}
\hline Urine & & Serology & \\
\hline Protein & $(+++)$ & C-reactive protein & $0.70 \mathrm{mg} / \mathrm{dl}$ \\
\hline Glucose & $(-)$ & Serum amyloid A protein & $7.2 \mu \mathrm{g} / \mathrm{ml}$ \\
\hline \multirow[t]{2}{*}{ Occult blood } & $(+++)$ & Immunoglobulin G & $1,073 \mathrm{mg} / \mathrm{dl}$ \\
\hline & & Immunoglobulin A & $220 \mathrm{mg} / \mathrm{dl}$ \\
\hline Erythrocyte sedimentation rate & $25 \mathrm{~mm} / \mathrm{h}$ & Immunoglobulin $\mathrm{M}$ & $60 \mathrm{mg} / \mathrm{dl}$ \\
\hline Peripheral blood & & Rheumatoid factor & $(-)$ \\
\hline White blood cells & $5,300 / \mathrm{mm}^{3}$ & Anti-unclear antibody & $(-)$ \\
\hline Neutrophil & $51 \%$ & TPHA & $(-)$ \\
\hline Eosinophil & $2 \%$ & Cryoglobulin & $(-)$ \\
\hline Basophil & $0 \%$ & HBsAg & $(-)$ \\
\hline Lymphocyte & $45 \%$ & Anti-HCV antibody & $(+)$ \\
\hline Monocyte & $2 \%$ & HCV-RNA & $0.55 \mathrm{Meq} / \mathrm{ml}$ \\
\hline Red blood cells & $416 \times 10^{4} / \mathrm{mm}^{3}$ & Anti-HTLV-1 Antibody & $(-)$ \\
\hline Hemoglobin & $12.8 \mathrm{~g} / \mathrm{dl}$ & & \\
\hline Hematocrit & $31.9 \%$ & Bone marrow examination & \\
\hline \multirow[t]{2}{*}{ Platelet } & $18.9 \times 10^{4} / \mathrm{mm}^{3}$ & Nuclear cell count & $73,500 / \mathrm{mm}^{3}$ \\
\hline & & Proerythroblast & $0.1 \%$ \\
\hline Blood chemistry & & Myeloblast & $2.0 \%$ \\
\hline Total protein & $4.9 \mathrm{~g} / \mathrm{dl}$ & Promyelocyte & $4.0 \%$ \\
\hline Albumin & $63.9 \%$ & Myelocyte & $8.0 \%$ \\
\hline$\alpha_{1}$-globulin & $7.7 \%$ & Metamyelocyte & $8.0 \%$ \\
\hline$\alpha_{2}$-globulin & $9.1 \%$ & Neutrophil & $26.8 \%$ \\
\hline$\beta$-globulin & $12.9 \%$ & Eosinophil & $1.2 \%$ \\
\hline$\gamma$-globulin & $6.4 \%$ & Basophil & $0.4 \%$ \\
\hline Total bilirubin & $0.4 \mathrm{mg} / \mathrm{dl}$ & Lymphocyte & $24.8 \%$ \\
\hline Asparate aminotransferase & $35 \mathrm{IU} / l$ & Monocyte & $4.4 \%$ \\
\hline Alanin aminotransferase & $32 \mathrm{IU} / \mathrm{l}$ & Plasma cell & $8.8 \%$ \\
\hline Alkaline phosphatase & $148 \mathrm{IU} / l$ & Erythroblasts & $10.0 \%$ \\
\hline$\gamma$-Glutamyltranspeptidase & $22 \mathrm{IU} / \mathrm{l}$ & Myeloid/Erythroid ratio & 5.2 \\
\hline Lactate dehydrogenase & $441 \mathrm{IU} / l$ & & \\
\hline Blood urea nitrogen & $21 \mathrm{mg} / \mathrm{dl}$ & & \\
\hline Creatinine & $0.8 \mathrm{mg} / \mathrm{dl}$ & & \\
\hline $\mathrm{Na}$ & $141 \mathrm{mEq} / \mathrm{l}$ & & \\
\hline $\mathrm{K}$ & $4.0 \mathrm{mEq} / \mathrm{l}$ & & \\
\hline $\mathrm{Cl}$ & $101 \mathrm{mEq} / \mathrm{l}$ & & \\
\hline
\end{tabular}

HCV: hepatitis C virus, HBsAg: hepatitis B surface antigen, HTLV-1: human T-cell leukemia virus type 1, TPHA: Treponema pallidum hemaggulutination test. 
A

Serum

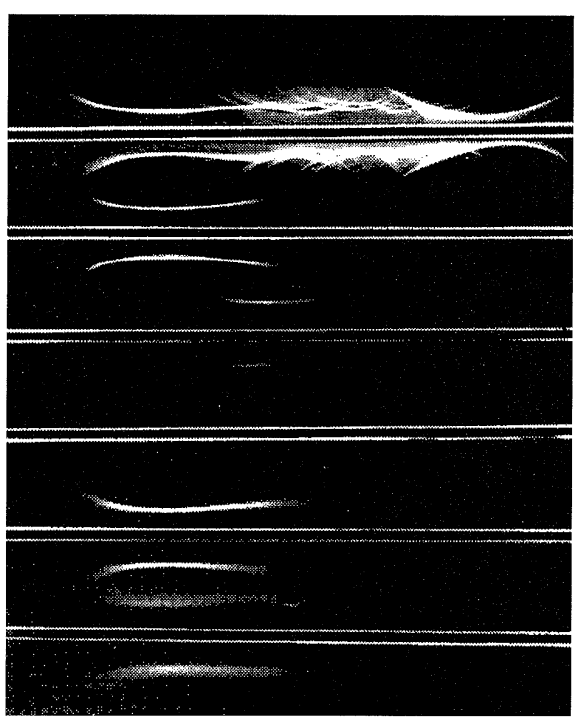

$\mathrm{B}$

Urine



Figure 2. Immunoelectrophoretic analysis. The serum (A) and urine (B) samples were subjected to immunoelectrophoretic analysis. The pattern in the serum sample is normal, but the pattern in the 100-fold concentrated urine sample reveals Bence Jones protein.

positive, and the level of HCV-RNA was $0.55 \mathrm{Meq} / \mathrm{ml}$ by a branched DNA assay. By immunoelectrophoretic analysis, the pattern in the serum sample was normal, but Bence Jones protein was detected in the 100 -fold concentrated urine sample, which contained monoclonal protein consisting of light chain lambda of immunoglobulin (Fig. 2). Bone marrow examination revealed normal cellularity and mild proliferation of plasma cells with its proportion of $8.8 \%$ (Table 1). T1-weighted magnetic resonance images showed macroglossia and narrowing of the respiratory airway (Fig. 3). However, bone X-ray, bone scintigram or ${ }^{67} \mathrm{Ga}$-scintigram did not reveal any active lesions. The biopsy specimen from the gastric mucosa showed marked AA amyloid deposits stained by the Congo red staining, which lost its affinity by pretreatment with $\mathrm{KMnO}_{4}$ (Fig. 4) $(14,15)$. Furthermore, immunohistochemical analysis showed positive staining of amyloid deposition by anti-AA antibody (Dako Japan, Kyoto) (Fig. 5). When the histologic examinations were performed in the tissues such as lip, kidney, inguinal lymph node and tongue, AA amyloid deposition was found in all the tissues studied.

To investigate the possible mechanism by which systemic amyloid deposition occurred in this patient, the degradation patterns of SAA protein by PBMC obtained from the patient or from healthy volunteers as a control with informed consent were analyzed by immunoblotting. In brief, SAA protein and polyclonal antibody to AA protein were kindly provided from Dr. N. Kubota (Eiken Chemical Ltd., Tochigi). PBMC were isolated from heparinized peripheral blood by Ficoll-Hypaque

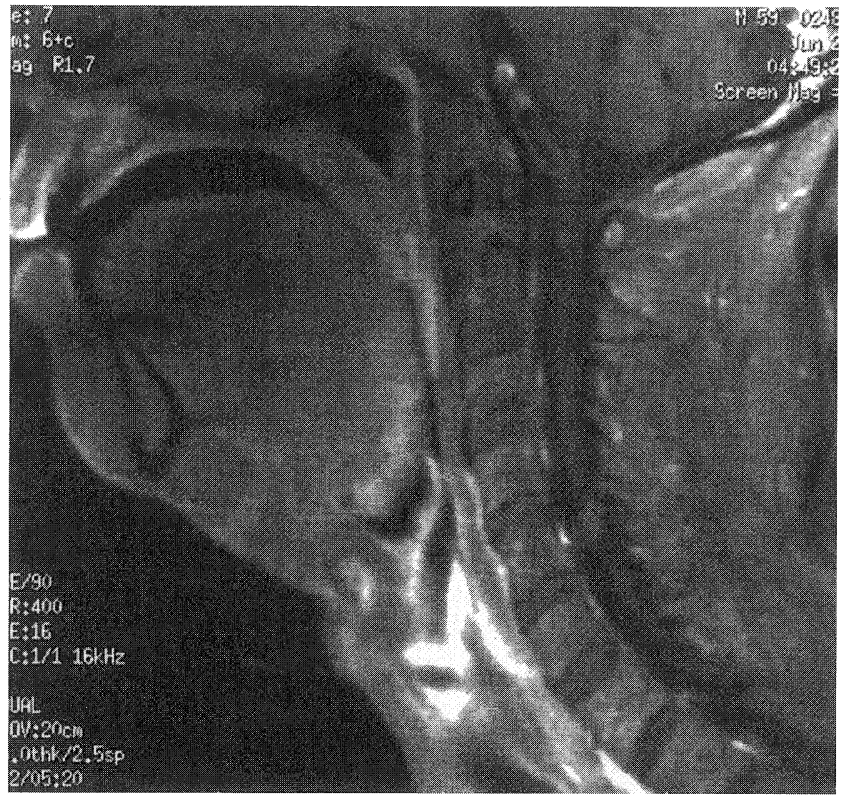

Figure 3. T1-weighted magnetic resonance image showing diffuse swelling of the tongue and narrowing of the respiratory way.

gradient $\left(\mathrm{d}=1.09 \mathrm{~g} / \mathrm{cm}^{3}\right)$ centrifugation, and the cells $\left(2 \times 10^{5}\right)$ were plated in 96 -well plates containing $200 \mu \mathrm{l}$ of serum-free RPMI culture medium in the presence of $10 \mu \mathrm{g} / \mathrm{ml}$ of SAA 


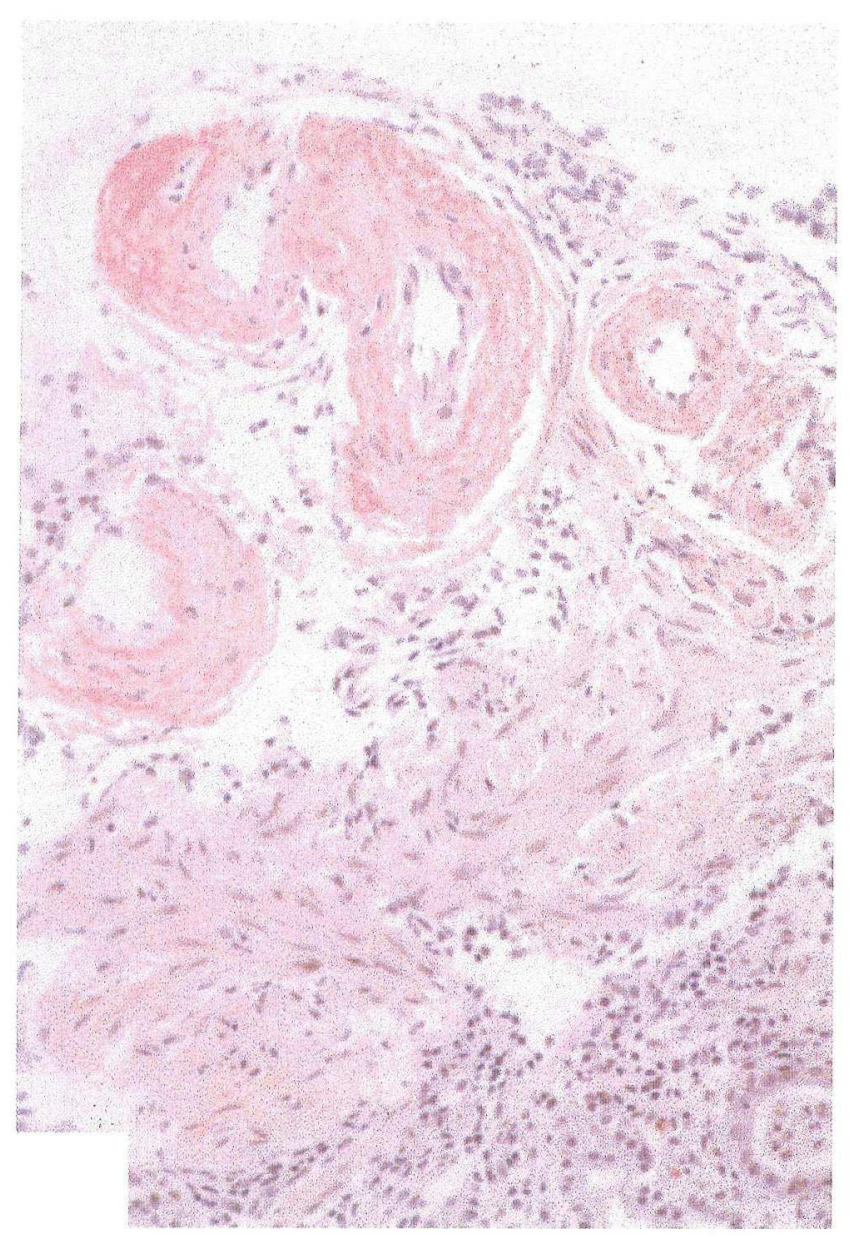

A

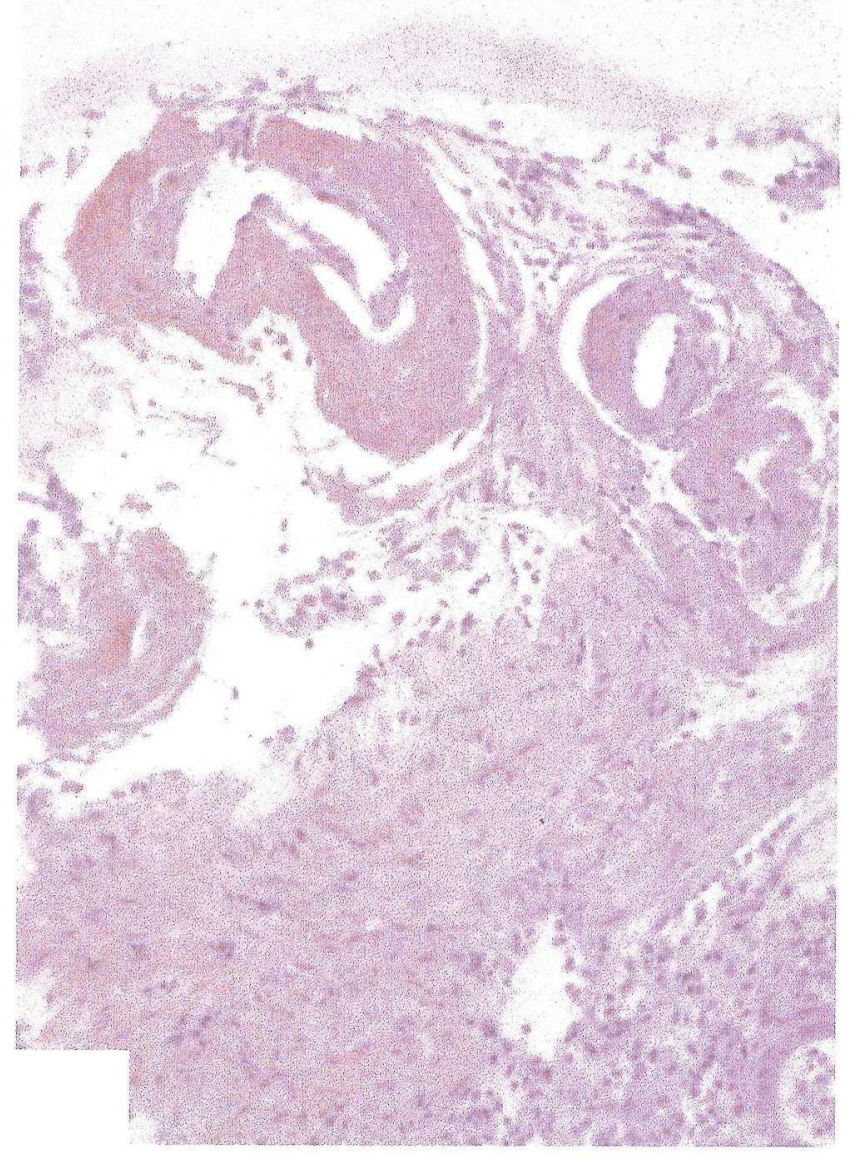

$\mathrm{B}$

Figure 4. Microscopic findings of gastric mucosa biopsy specimen on Congo red staining, showing marked AA amyloid deposits (A), and the Congo red affinity is lost by pretreatment with $\mathrm{KMnO}_{4}(\mathrm{~B})(\times 100)$.

protein. Aliquots of supernatants were collected at 6,12 and 24 hours after incubation and analyzed for the degradation of SAA protein by immunoblotting using anti-AA antibody as described previously (11). As shown in Fig. 6, SAA protein was digested to the degradated product rapidly by PBMC from healthy volunteers with the disappearance of SAA protein at 12 hours after incubation. In contrast, the degradation rate was very slow in the present patient, and SAA protein was detected even at 24 hours after incubation.

Treatment with diuretics such as furosemide and spironolactone was started at the time of admission for the control of the leg edema and congestive heart failure probably associated with the amyloid deposition. Dimethyl sulfoxide was also given orally after AA amyloid deposition was defined histochemically. The leg edema was reduced by diuretic treatment, but dysphagia and dysarthria together with macroglossia, swelling of the submandibular soft tissue and proteinuria continued despite the treatment during the observation period.

\section{Discussion}

In the present case, the diagnosis of AA amyloidosis was based on the histochemical analysis. The amyloid deposition was detected in a variety of tissues, which was susceptible to pretreatment with $\mathrm{KMnO}_{4}(14,15)$. In addition, the amyloid deposition was reactive with anti-AA antibody by means of immunostaining. In general, in the majority of patients, AA amyloidosis accompanies active inflammatory diseases with elevated levels of serum CRP and SAA protein $(9,10)$. However, in our case, these values ranged almost within the normal limits during the follow-up period, and no active inflammatory lesion could be found. By immunoelectrophoretic analysis in the urine sample, Bence Jones protein was detected, while only mild elevation of the proportion of plasma cells was seen in the bone marrow sample. A sampling error in bone marrow tapping was a possible cause of the discrepancy, but bone Xray, bone scintigram or ${ }^{67} \mathrm{Ga}$-scintigram did not detect any ac- 


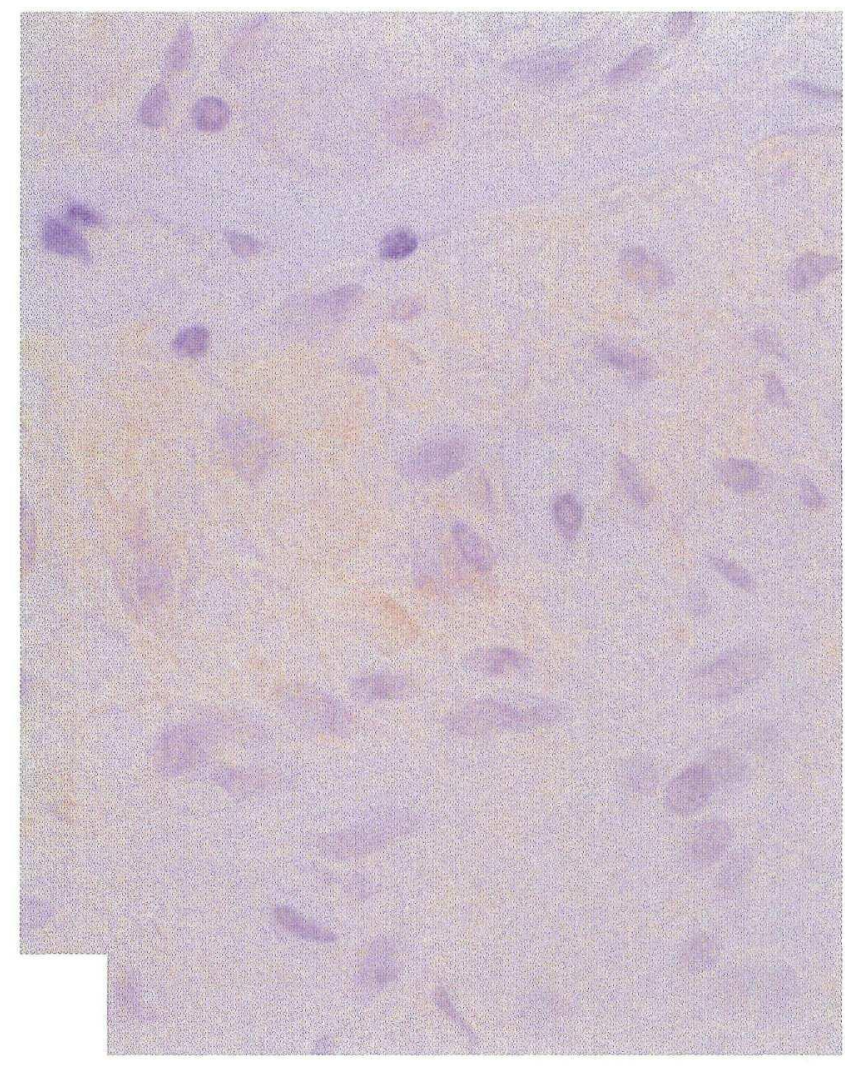

A

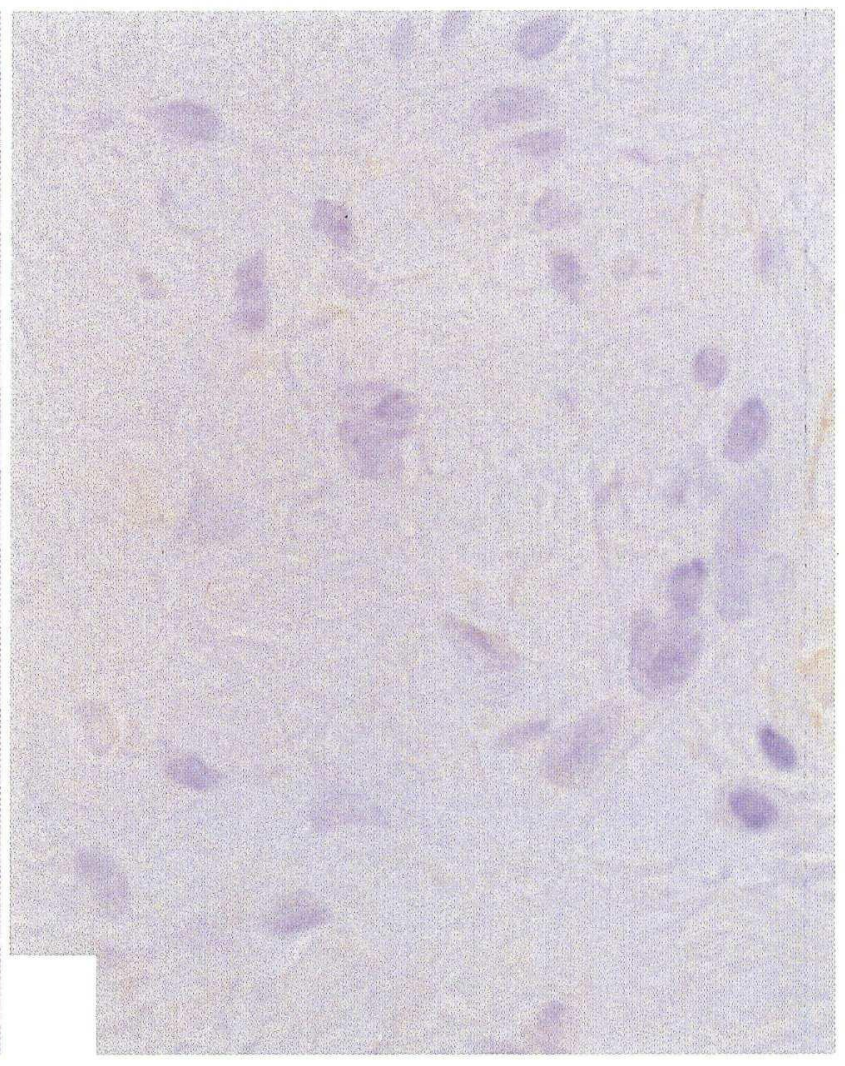

$\mathrm{B}$

Figure 5. Immunostaining of the gastric mucosa biopsy specimen, showing the positive staining of amyloid deposition by antiAA antibody (A) but not anti-lamda antibody $(\mathrm{B})(\times 400$, respectively).

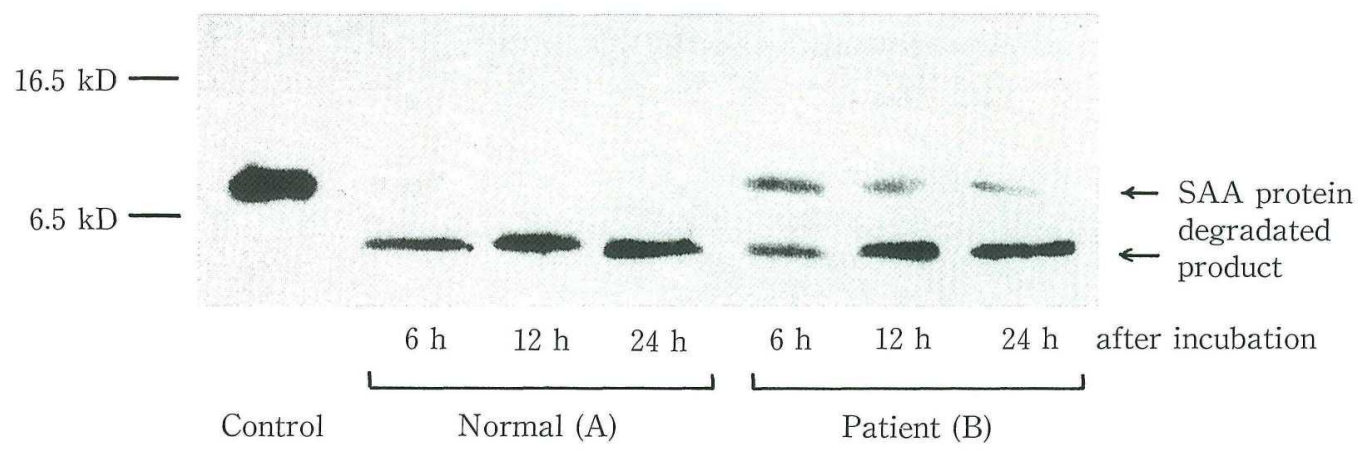

Figure 6. Immunoblot analysis for degradation of SAA protein by PBMC. PBMC were obtained from the patient and five normal volunteers. The PBMC-mediated degradation of SAA protein in normal volunteers was rapid, and only the degradated product was seen at 12 hours after incubation (A), whereas the degradation rate in our patient was slow, and SAA protein was detected until 24 hours after incubation (B).

tive lesions in our case. Previous studies showed that Castleman's disease which is considered to be a hamartoma or hyperplasia of the lymphoid tissue is often associated with AA amyloidosis $(16,17)$. In most of these cases, the levels of se- rum CRP and SAA protein were elevated, and AA amyloid deposition was induced by overexpression of cytokines including interleukin- 6 by lymphoid cells $(17,18)$. In our case, systemic lymphadenopathy was observed, but the histological 
examination revealed only AA amyloid deposition in the lymphoid tissue without any findings of the tumorous lesion as well as in other tissues. Based on these results, the diagnosis of AA amyloidosis with plasma cell dyscrasia was made in our case, although the relationship between the two diseases could not be elucidated. Recent studies have demonstrated the association of $\mathrm{HCV}$ infection with the mixed-type cryoglobulinemia and non-Hodgkin B-cell lymphoma $(19,20)$. In addition, several investigators have shown the presence of $\mathrm{HCV}$ in PBMC and bone marrow cells $(21,22)$. The altered regulation of Bcells by HCV might participate in the pathogenetic process in our case.

The mechanism by which deposition of AA amyloid occurs in some patients with chronic inflammatory disease is not fully understood. Our patient received interferon- $\alpha$ treatment for chronic hepatitis $\mathrm{C}$, but its relevance to the AA amyloid deposition was unlikely because of the interval of 4 years from interferon- $\alpha$ treatment to the clinical manifestations of AA amyloidosis. The increased level of SAA protein, a precursor of AA amyloid, and the reduced ability to degrade the amyloid fibrils are believed to be important roles in the pathogenesis of AA amyloidosis $(9,23)$. However, severe inflammation is not always essential in the development of AA amyloidosis, and the increased circulating proteolytic cleavage of SAA protein may influence the development of AA amyloid deposition (11). Furthermore, Ham et al. have recently shown that macrophages obtained from mice susceptible to the development of AA amyloidosis have some defects in the degradative activity of SAA protein (13). In the present case, the degradation of SAA protein by PBMC was impaired. Thus, the delayed degradation of SAA protein is likely to contribute to the pathogenesis of AA amyloidosis in this case as well as in patients with secondary amyloidosis, although other factors such as amyloid $\mathrm{P}$, heparan sulfate proteoglycan or apoprotein $\mathrm{E}$ affect the amyloid fibril deposition (24-27).

In summary, we reported a case of AA amyloidosis with plasma cell dyscrasia manifested during the follow-up period of chronic inactive hepatitis C. By the immunoblot analysis, the delayed degradation of SAA protein by PBMC was found in our case. This would be a possible factor leading to AA amyloid deposition, although many other factors can also be involved in its pathogenesis.

\section{References}

1) Glenner GG. Amyloid deposits and amyloidosis: The beta-fibrilloses (first of two parts). N Engl J Med 302: 1283-1292,1980.

2) Glenner GG. Amyloid deposits and amyloidosis: The beta-fibrilloses (second of two parts). N Engl J Med 302: 1333-1343, 1980.

3) Gertz MA, Kyle RA. Secondary systemic amyloidosis: response and survival in 64 patients, Medicine (Baltimore) 70: 246-256, 1991.

4) Falk RH, Comenzo RL, Skinner M. The systemic amyloidoses. N Engl J Med 337: 898- 909, 1997.

5) Kyle RA, Gertz MA. Primary systemic amyloidosis: clinical and laboratory features in 474 cases. Semin Hematol 32: 45-59, 1995.

6) Murakami T, Uchino M, Ando M. Genetic abnormalities and pathogen- esis of familial amyloidotic polyneuropathy. Pathol Int 45: 1-9, 1995.

7) Coelho T. Familial amyloid polyneuropathy: new developments in genetics and treatment. Curr Opin Neurol 9: 355-359, 1996.

8) Reilly MM, Staunton H. Peripheral nerve amyloidosis. Brain Pathol 6: 163-177, 1996.

9) Benson MD, Cohen AS. Serum amyloid A protein in amyloidosis, rheumatic, and neoplastic diseases. Arthritis Rheum 22: 36-42, 1979.

10) Kisilevsky R. Amyloidosis: a familiar problem in the light of current pathogenetic developments. Lab Invest 49: 381-390, 1983.

11) Migita $K$, Eguchi $K$, Tsukada $T$, et al. Increased circulating serum amyloid A protein derivatives in rheumatoid arthritis patients with secondary amyloidosis. Lab Invest 75: 371-375, 1996.

12) Lavie G, Zucker-Franklin D, Franklin EC. Degradation of serum amyloid A protein by surface-associated enzymes of human blood monocytes. J Exp Med 148: 1020-1031, 1978.

13) Ham $D$, Caouras V, Radzioch $D$, Gervais F. Degradation of amyloid $A$ precursor protein SAA by macrophage cell lines obtained from amyloid resistant and susceptible strains of mice. Scand J Immunol 45: 354-360, 1997.

14) Wright JR, Calkins E, Humphrey RL. Potassium permanganate reaction in amyloidosis. A histologic method to assist in differentiating forms of this disease. Lab Invest 36: 274-281, 1977.

15) van Rijswijk MH, van Heusden CW. The potassium permanganate method. A reliable method for differentiating amyloid AA from other forms of amyloid in routine laboratory practice. Am J Pathol 97: 43-58, 1979.

16) Tanaka $\mathrm{K}$, Horita $M$, Shibayama $\mathrm{H}$, et al. Secondary amyloidosis associated with Castleman's disease. Intern Med 34: 122-126, 1995.

17) Ikeda $S$, Chisuwa $H$, Kawasaki $S$, et al. Systemic reactive amyloidosis associated with Castleman's disease: serial changes of the concentrations of acute phase serum amyloid A and interleukin 6 in serum. J Clin Pathol 50: $965-967,1997$.

18) Moshage HJ, Roelofs HM, van Pelt JF, et al. The effect of interleukin-1, interleukin- 6 and its interrelationship on the synthesis of serum amyloid $\mathrm{A}$ and C-reactive protein in primary cultures of adult human hepatocytes. Biochem Biophys Res Commun 155: 112-117, 1988.

19) Zignego AL, Ferri $C$, Giannini $C$, et al. Hepatitis $C$ virus infection in mixed cryoglobulinemia and B-cell non-Hodgkin's lymphoma: evidence for a pathogenetic role. Arch Virol 142: 545- 555, 1997.

20) Zuckerman E, Zuckerman T, Levine AM, et al. Hepatitis $C$ virus infection in patients with B-cell non-Hodgkin lymphoma. Ann Intern Med 127: 423-428, 1997.

21) Chang TT, Young KC, Yang YJ, Lei HY, Wu HL. Hepatitis C virus RNA in peripheral blood mononuclear cells: comparing acute and chronic hepatitis C virus infection. Hepatology 23: 977-981, 1996.

22) Sansonno D, Iacobelli AR, Cornacchiulo V, Iodice G, Dammacco F. Detection of hepatitis $\mathrm{C}$ virus (HCV) proteins by immunofluorescence and HCV RNA genomic sequences by non-isotopic in situ hybridization in bone marrow and peripheral blood mononuclear cells of chronically HCVinfected patients. Clin Exp Immunol 103: 414-421, 1996.

23) De Beer FC, Mallya RK, Fagan EA, Lanham JG, Hughes GR, Pepys MB. Serum amyloid-A protein concentration in inflammatory diseases and its relationship to the incidence of reactive systemic amyloidosis. Lancet 2 : 231-234, 1982

24) Skinner M, Cohen AS, Shirahama T, Cathcart ES. P-component (pentagonal unit) of amyloid: isolation, characterization, and sequence analysis. J Lab Clin Med 84: 604-614, 1974.

25) Westermark P, Skinner M, Cohen AS. The P-component of amyloid of human islets of langerhans. Scand J Immunol 4: 95-97, 1975.

26) Snow AD, Bramson R, Mar H, Wight TN, Kisilevsky R. A temporal and ultrastructural relationship between heparan sulfate proteoglycans and $\mathrm{AA}$ amyloid in experimental amyloidosis. J Histochem Cytochem 39: 13211330, 1991.

27) Wisniewski T, Frangione B. Apolipoprotein E: a pathological chaperone protein in patients with cerebral and systemic amyloid. Neurosci Lett 135: 235-238, 1992. 